\title{
OVERVIEW OF THE SUPPORT SYSTEM OF IMPLEMENTATION OF THE FCC: FAMILY, NURSE, AND THE HOSPITAL ENVIRONMENT
}

\author{
Eva Supriatin*, Diwa Agus Sudrajat, Fitri Nurhayati, Linlin Lindayani \\ STIKep PPNI Jawa Barat Bandung, Indonesia \\ *E-Mail: evatarisa@gmail.com
}

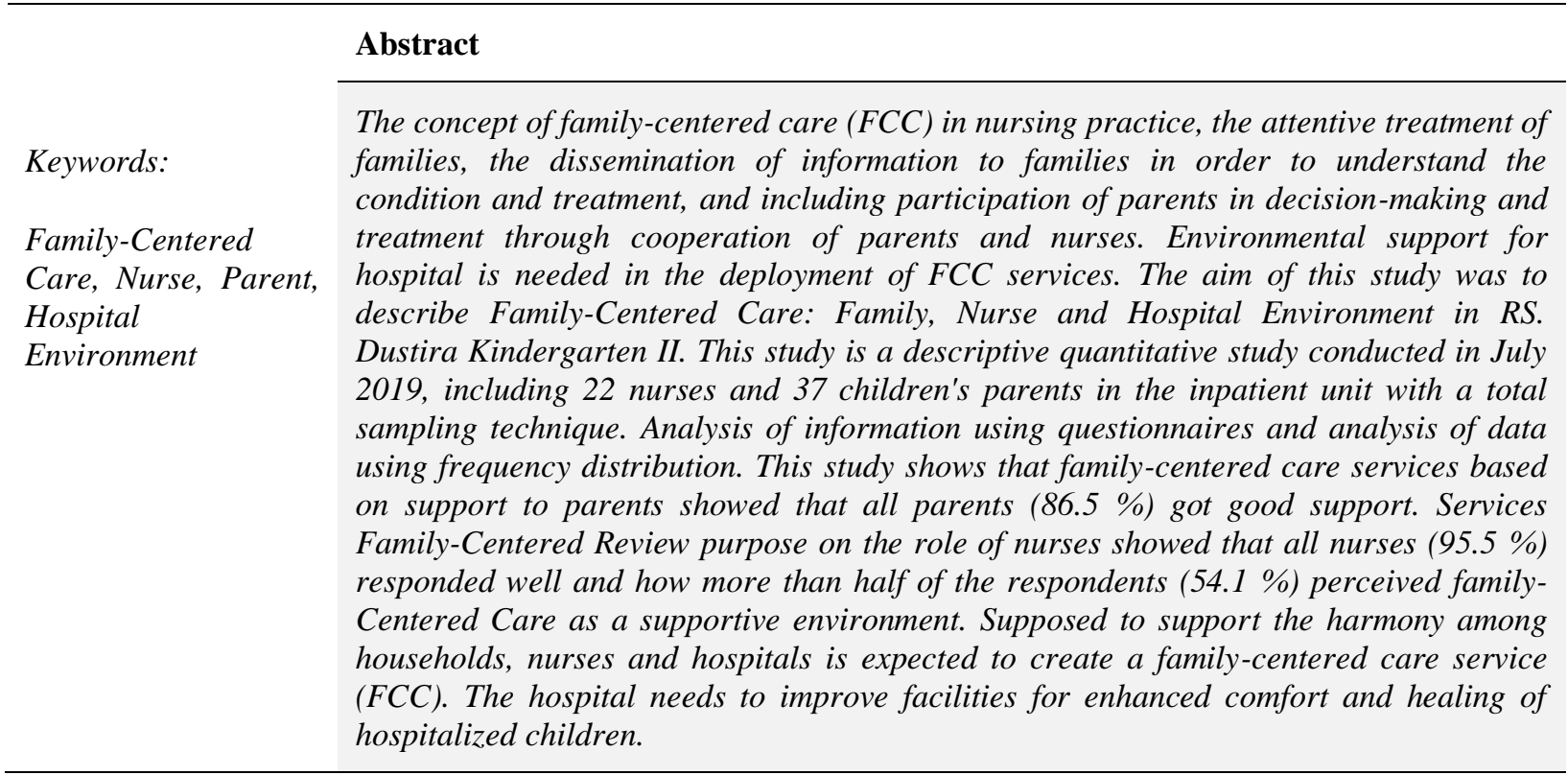

\section{INTRODUCTION}

Hospitalization is a crisis in children when the child is sick and in hospital, then it must be adjusted to the hospital environment (Wong \& others, 2009). Children's hospitalization is a horrific experience for both the child and the parents. The number of stressors experienced by children while hospitalization has a negative impact that disrupts the development of Roberts' children (Utami, 2014). Wright (Apriany, 2013) in his study on the effects of hospitalization on children's behavior states that children's reactions to hospitalization are primarily sad, fearful, and guilty because they face something that has never been experienced before: insecurity, discomfort, feelings of loss.
Something that has now been commonly experienced and something painful.

The morbidity rate for children in Indonesia based on the 2015 National Health Survey (Susenas) in urban areas in age group 0-4 years is 25.8 per cent, 5-9 years is 20.00 per cent, $10-14$ years is 14.00 per cent, $15-19$ years is 10.00 per cent. Children who are hospitalized have an effect on physical and psychological condition. Children have a very vulnerable condition, especially in situations of stress. The emergence of challenges that children must face, such as overcoming separation, adjusting to a new environment, and adjusting to all of the people who take care of them, especially nurses (Utami, 2014).

Nurses as health care providers who assist patients for 24 hours must 
contribute to their role as caregivers, in especially helping children and families to have positive experiences during hospitalization. Child nurses must have a deeper understanding of growth and development in order to develop appropriate nursing care to help children and families adapt to conditions that affect both externally and internally growth and development. Potter \& Perry (De Fretes, 2012)

During the nursing process, the family is considered to the be the nurse's partner to optimize the child's growth and development. The two concepts surrounding this family are to make it possible for the family to be actively involved in the nursing care of their children in the hospital and to empower the family both in terms of knowledge, skills and attitudes to child care in the hospital and by therapeutic interactions with the family ( empowering ). The main forms of intervention needed by children and their families are support, health care and referrals to other competent health workers provided on the needs of the child (Supartini, 2004)

Nursing services, especially in children, namely family-based care (FCC) is an approach to the planning, delivery and evaluation of health services, patients and families. Its relationship in health care is changing. Patients and family-based care practitioners recognize the important role which family members play in ensuring the health and well-being of infants, children, adolescents and family members of all ages. Family-based care recognizes that emotional, social and developmental support is an integral part of health services so that it can improve the health, well-being of individuals and families. Institute for Care and Family Care (Yugistyowati \& Wahyuningsih, 2015).

The FCC concept of nursing practice, the care of families with care, the sharing of information to families in order to understand the condition and care of their children, the participation of parents in decision-making and child care, and cooperation between parents and carers. The FCC is a family nurse who performs nursing skills (Dunst \& Trivette, 2009) . The family is used as a service unit and health problems are interrelated and affect each other and the families around them. In the healthcare sector, the family has duties in the health sector that need to be understood and carried out, family support is a form of family service behavior, both in the form of emotional support, appreciation support, information support and support in the form of instrumental Tumenggung (H, 2017). FCC applications and hospital environmental facilities include policies and facilities. Policies related to hours of access, pre-consultation, and procedures. Meanwhile the facilities include a special study room for children, a parents' bed, a Longue, photos, a telephone, a playroom, a library and a consultation room. (Kusumaningrum, 2010). FCC has long been developed as a caring approach with a family approach, but this development has not been optimal in Indonesia with (Wantiyah et al., 2018) Hendrawati et al.

Every care for children who are hospitalized requires the involvement of the parents. The nurse, as one of the health workers in the hospital, plays a very important role, one of which is health services in the form of direct nursing and health education for children and also for families (Supartini, 2004) The concept of "Family-Centered Care" as a philosophy for providing nursing services in hospitals is an approach that can be done and in this approach, there is a reciprocal relationship between service providers, nurses and families in order to minimize conflicts that arise due to lack of information and communication (Kusumaningrum, 2010)

The hospital is a provider of curative and rehabilitative health services that are integrated with the implementation of promotion and preventive health programs, including the Dustira Cimahi Kindergarten II Hospital, to become the 
largest referral hospital. Dustira Hospital was accredited to KARS 2012 in 2014, where Dustira Hospital is a study for other hospitals. Dustira Hospital has won a range of awards, such the Rank 1 Award for Mother and Baby Hospital (RSSIB) at the West Java Province level in 2015 and the Best Hospital Service Excellent Award of the Year in 2018. This shows that the Dustira Hospital has advantages in providing services, one of which is providing services to mothers and children.

Seeing the importance of family support, the role of nurses and the homebased environment in applying the FCC concept in the hospital. On the background of the above, the authors are interested in the description of Family members Care: Family, Nurses, and Hospital Environment for Children who are hospitalized in a hospital. TK II Dustir Cimahi, 2019.

\section{METHOD}

This research uses a descriptive quantitative method. The variables in this study were Family-Centered Care, Family, Care, and Hospital Environment. This research was conducted in the pediatric inpatient room (salak room) RS. Dustira Cimahi Kindergarten II. The study was conducted on 3 on 22 July 2019. The population in this study is the family (parents, mother/father) and nurses in the hospital in inpatient children. Dustira Cimahi Kindergarten II. A total of 37 people (parents, mother/father) and 22 nurses. The sampling technique is empirically $\mathrm{n}$ using the technique of total method by taking all the nurses and parents in the hospital room of the child. TK II Dustir Cimahi fit the inclusion criteria. The inclusion criteria for taking the study sample were parents (mother/father) of children who were hospitalized for more than 2 consecutive days waiting for patients in the hospital, parents (mother/father) who were able to read and write, nurses who served children in the hospital room, and Willing to be the respondent.

The questionnaire in this study uses types of questionnaires. The Family-Centered Care questionnaire was used to measure nurses and families. The questionnaire used is in the form of a checklist compiled on the principle of the Likert model measurement scale. The questionnaire will be filled out to the respondent by adding a checkmark on the item used to measure the variable Family-Centered Care for Families and Nurses consisting of 4 frequency band with a scoring determination consisting of Famously (positive statements) and unfavorable items (negative statements). The determination of the results of the description of the implementation of the Family-Centered Care was used in three groups, namely good, adequate and insufficient. The category of scoring is calculated of the results of the evaluation of the mean using SPSS 23 for windows. Based on the results of these calculations, an Overview Category of Family-Centered Care Services is created: Hospital Environment with Respondents with a score of > 21.81 perceiving that the Hospital Environment supports FamilyCentered Care Services. In the meanwhile, respondents with a score $<21,81$ think that the hospital environment may not support family-centered care services.

The data collection technique used in this study was to use a questionnaire completed by the respondents in this study on 18-22 July 2019. The questionnaire was distributed directly to the respondents by the researcher, the respondents completed the questionnaire with complete data, and the questionnaire with the parent respondents was collected on the same day, namely on 18 July 2019 and on 22 July 2019. Questionnaires with nurse respondents returned to the researcher on another day on 18 July 2019 and returned on 22 July 2019. 


\section{Data analysis}

Data were analyzed using the Windows SPSS 23 computer program or the data were analyzed using Univariate Analysis in this study. This study uses a frequency distribution analysis method, which is a collection of data (frequency) presented in tabular form, the with aim to identify the condition of the overall dimensions studied and presented in tabular form (Sopingi, 2015). The normality test in this study uses Shapiro-Wilk, the data are seen to be normal if the significant value is greater than $0.05(\mathrm{P}>0.05)$. Conversely, if the significant value at $(\mathrm{P}<0.05)$ is less than 0.05 , the data is said to be abnormal. The results of the normality test in this study were significant in the parent sample (0.287) indicating that the distribution of the sample was normal. The hospital environment (0.370) has a normal distribution. For the nurse sample, the normality test is calculated from Skewness by dividing the statistical results with Std. Error expected for being $\pm 3=$ Normal. This calculation indicates the results (1.18) indicating that the distribution is normal.

\section{RESULT}

\section{Parent respondent character}

\begin{tabular}{|c|c|c|}
\hline Characteristic & $\mathbf{n}$ & $\%$ \\
\hline \multicolumn{3}{|l|}{ Age of the parents } \\
\hline 20-40 Year & 31 & 83,8 \\
\hline 41-60 Year & 6 & 16,2 \\
\hline \multicolumn{3}{|l|}{ Parental Education } \\
\hline Primary school & 2 & 5,4 \\
\hline Junior High School & 4 & 10,8 \\
\hline Senior High School & 14 & 37,8 \\
\hline College & 17 & 45,9 \\
\hline \multicolumn{3}{|l|}{ Parents' Income } \\
\hline$<1.000 .000$ & 5 & 13,5 \\
\hline$>1.000 .000$ & 2 & 5,4 \\
\hline$>2.000 .000$ & 30 & 81,1 \\
\hline Total & 37 & 100 \\
\hline
\end{tabular}

This study shows that almost all parents have been between 20 to 40 years of age $(83.8 \%)$. Mostly on grounds of the education level of the respondents, SMA (37, 8\%) and higher education are mostly high $(45.9 \%)$. Almost all parents have salaries of more than Rp 2 million $(81,1 \%)$.

Family Care Services based on parental support

Table 2 Distribution of family care services based on parental support $(n=37)$

\begin{tabular}{lcc}
\hline Category & $\mathrm{n}$ & $\%$ \\
\hline Less & 0 & 0 \\
Enough & 5 & 13.5 \\
Good & 32 & 86.5 \\
Total & 37 & 100 \\
\hline
\end{tabular}

The table above shows that almost all parents $(86.5 \%)$ provide good support of parents care services in the pediatric hospital room. Dustir Cimahi kindergarten. 
Family Care Services Focused on the Impact of Nurses

Table 3 Distribution of family care services based on the role of nurses $(n=22)$

\begin{tabular}{|c|c|c|}
\hline Category & $\mathrm{n}$ & $\%$ \\
\hline Less & 0 & 0 \\
\hline Enough & 1 & 4.5 \\
\hline Good & 21 & 95.5 \\
\hline Total & 22 & 100 \\
\hline
\end{tabular}

The table above shows that almost all nurses $(95.5 \%)$ played a good role in parents care in the hospital's pediatric hospital room. Dustira Cimahi Child's Field II.

\section{Relatives care services based on the environment of a hospital}

Table 4 Distribution of family care services based on a environment of a hospital $(n=37)$

\begin{tabular}{lcc}
\multicolumn{1}{c}{ Category } & $\mathrm{n}$ & $\%$ \\
\hline Support & 20 & 54.1 \\
Does not support & 17 & 45.9 \\
\hline Total & 37 & 100 \\
\hline
\end{tabular}

The table above shows that most of the respondents (54.1\%) feel that the hospital environment supports parents care services.

\section{DISCUSSION}

\section{Services Family-Centered Care is based on support by parents.}

Based on the results of the study, it can be seen that almost all parents (86, 5 per cent) provide good support to family-based care in the children's hospital. Dustira Cimahi Kindergarten II. Family-Centered Care is a philosophy in which caregivers prioritize and play an important role, family support that builds strength, helps make the best choices and strengthens the child's normal pattern throughout healing (Peterson, Cohen, \& Parson, 2004). In familycentered care, family support is a constant part of a child's life. The family is involved in decision making, nurturing and educating the care system. Families must be involved in providing health services to their children, the role of parents is to support children emotionally and as providers for children. The information about the child from the nurse must be well received by the parents.

These results are the same as the results of the research conducted previously by (De Fretes, 2012)entitled The Relationship of Family-Centered Care with the Effects of Hospitalization on Children in the Cilasa Cilasa Hospital Dahlia Room, Semarang, that there is a relationship between Family-Centered Care: Parents with hospitalization effects on children. Based on research conducted by (Endah, 2018)parental support may well be influenced by age factors in growth and development, and will have an understanding of the different responses to changes in health. Based on the results of the study, almost all parents from 20 to 40 years of age can be seen from the characteristics of the parent respondents $(83,8 \%)$. This age is included in the Hurlock category of early adulthood (Jahja, 2015).

(Endah, 2018) stated in their research that this early adult age group is very supportive of overcoming children's anxiety during invasive actions. Where early adulthood is responsible for their activities, including the protection and safety of children. This is also the Hurlock concept in (Jahja, 2011) that early adults have maximum body strength, are ready to produce, and have cognitive, affective, and psychomotor readiness.

In this study, the parents accompany the child while undergoing treatment, the parents respond after the child has taken care of the child, the parents understand the advice provided by the nurse, the parents pay all the expenses that the child needs while being treated, such as the cost of medication and care, 
and the parents report quickly. (Endah, 2018) reported in their research that this early adult age group is very tolerant of overcoming children's fear during intrusive acts. Where early adulthood is responsible for their behaviors, including the care and welfare of infants. This is also the Hurlock principle in (Jahja, 2011) that early adults have full body ability, are able to produce, and have cognitive, affective, and psychomotor preparation.

In this research, the parents accompany the child when receiving therapy, the parents reply after the child has taken care of the child, the parents understand the guidance given by the nurse, the parents cover all the costs that the child needs when being handled, such as the cost of medication and care, and the parents report immediately. On the basis of education-level research, most of the respondents are highly educated, cognitive abilities will shape a person's way of thinking, including the ability to understand disease-related factors and to use health knowledge to maintain the health of his or her family (Endah, 2018).

In this study, parents educate children while undergoing treatment, parents can work together to make decisions about child care while being treated, and contribute to child care by providing nurses with information about the child's condition. Parents immediately get updates and access to the child's diagnosis, an explanation of the protocol for taking action on the child, a doctor's appointment schedule, services that can be used in the hospital, and a payment system for medication fees. This indicates that the educational and informational support element for successful parent respondents favors family-based care programs.

Other factors influencing parental support other than age and educational factors according to (Endah, 2018), including socio-economic factors. The higher the economic status of an individual, the better they react to the effects of an illness they feel. So they will automatically get treatment should they believe there is an issue with their wellbeing. This is consistent with the findings obtained for nearly all seniors' income > Rp 2 million (81, 1 percent ). This means that the higher the parents' income, the more parents have everything the child wants, the more parents value the child. (Endah, 2018) This is in keeping with the BKKBN markers of a prosperous household, which state that if a family member is ill, they are taken to a health center.

In this report, the parents listened well to the nurses' statements about the payment structure for child care costs, or the use of health benefits, taking care of their health insurance, and the value of parental participation in any child's care so that parents could easily take sufficient steps to fulfill their needs. The infant as long as the child is in hospital. This indicates that the socio-economic or income conditions that are associated with the instrumental assistance offered by these parents support the family-centered care programs well.

\section{Services Family-Centred Care is focused around the role of nurses.}

Centered on the findings of the research performed in the RS Children's Inpatient Space. TK II Dustira Cimahi, nearly all nurses $(95,5$ per cent) played a strong role in family-based treatment. In line with the values of family-centered treatment, nursing professionals listen to and value the opinions and choices of patients, interact and exchange useful knowledge to patients and families equally and impartially with patients and families. As a motivator who supports and respects the family in caring for children, the nurse also encourages social and emotional wellbeing and addresses the needs of children in the family. Nurses must provide parents with complete and consistent statistics, provide parents with information that they believe is part of child care, and extend a holistic approach to children and communities so 
that the family can proceed through each level of growth well. The role of the nurse as a counselor or consultant who continues to communicate any decisions that will be made regarding child care with parents.

This result is different from the research conducted by (De Fretes, 2012) entitled The Relationship of FamilyCentered Care with the effects of hospitalization on children in the dahlia room of the Cilasa Cilasa Hospital, Semarang, which states that there is no relationship between Family-Centered Care: Nurses and hospitalization effects. in children. But the role of nurses in Family Centered Care services that are done well by nurses supports the research of (Dunst \& Trivette, 2009) that in nursing practice the concept of Family-Centered Care is applied in the form of treating families with care, conveying information to families so that they understand the condition and care for their children, involving the participation of parents in decision-making and child care, as well as cooperation between parents and caregivers. In this study, the role of nurses as advocates is carried out by assisting when parents need help such as difficulties in making choices, treatment, providing explanations related to available services, and procedures involving families. The role of nurses as educators is carried out by fulfilling the need for an understanding of treatment, care, a basic understanding of children's diseases, child care while being hospitalized, and further care in preparation for returning home to parents. Also the role of the nurse as a coordinator by always involving the family and working together with the family in the whole series of child care processes. In this study, the role of nurses as researchers is still less important, the role of nurses as researchers who must think critically in seeing everyday phenomena to improve the quality of nursing practice/care in children by examining nursing problems.

\section{Services Family-Centered Care by the hospital environment}

The results of the study based on the hospital environment on Family-Centered Care services showed that most of the respondents $(54,1 \%)$ perceived that the hospital environment was supportive of Family-Centered Care services. In the elements of Family-Centered Care, according to Harson in (De Fretes, 2012) policies related to scheduling activities such as bath time, eating, watching television, and playing with children while being treated will help children adapt. Providing a clear understanding of the procedure to be performed, and providing a positive experience during treatment will add to the experience in the future. Also, visits are made at the family home or in another place with a time and location that is mutually agreed upon by the family, home care services, counseling services, health promotion, play programs, and good health service coordination to help families take advantage of existing health services. To support the funding demands of the health service. Health facilities must be freely available to families, such as the billing method for health services used when the infant is receiving hospital treatment by either insurance or public and private health insurance, medical advice, and so on.

This is in line with the (Kusumaningrum, 2010) report, which notes that the implementation of familycentered treatment in child care includes all facets of policies and facilities relevant to the synergy of child care. The child care transition phase includes all recovery activities from the hospital intake procedure, mitigating separation disorder, minimizing power failure, minimizing damage and discomfort. In this report, according to family expectations, the healthcare atmosphere that promotes family-centered care programs is a strategy in the pediatric hospital system. TK II Dustira Cimahi, like adults, is permitted to stay with children for 24 hours without a 
visit time limit, parents are included in the test, and parents are given specific information by the nurse when answering questions or when the operation is to be carried out. This is in line with the findings of the (Kusumaningrum, 2010) that the policy on visiting hours is focused on the principle of family-centered treatment, that the family is seen as a constant factor, that the presence of the health profession fluctuates, that the mentoring of children by parents for 24 hours without any limitations on visiting hours is optimal and would offer support to children and parents. Advising or providing specific knowledge privileges on healthcare protocols, practices and legislation by health professionals to clients, respecting children and relatives when answering questions, is a concept of family-centered treatment, namely the integrity and reputation of nurse practitioners listening to and respecting the opinions and desires of patients. The idea of exchanging information with nursing professionals expresses and delivers valuable information to patients and families in a right, full and reliable manner to engage in treatment and decision-making, as well as in coordination in policy-making, execution and assessment of care delivery.

In addition to the study outcome policy of (Kusumaningrum, 2010), the facility is promoting the application for family-centered treatment for children who are hospitalized. Almost half of the respondents $(45,9 \%)$ thought that the healthcare climate did not help familycentered treatment programs in the findings of this report. This is attributable to services that promote family-centered treatment in the hospital. TK II Dustira Cimahi is not yet available, such as a decorated room (room setting, colour, pictures), a children's playroom, and a range of games ( Toys in the pediatric room). (Kusumaningrum, 2010) said in his research that a decorated child's room will increase the child's happiness, and that an activity room could minimize children's anxiety. The provision of a playroom and a variety of games will help and promote growth and development, minimize the risk of anxiety, panic and hospitalization. There is also no place for parents to meet, talk, share information, or exchange stories. The presence of a special place for parents to meet will enhance the support group for parents, share stories and perspectives when reading the available booklets will offer useful experience, strengthen expertise and family skills in child care. Children's libraries that offer activities for children who are cared for can guarantee that children access treatment in line with their needs, i.e. the need for understanding and thought is often not present at the hospital. Dustira Cimahi Children's Garden II.

\section{Research Limitations}

This study has not been undertaken in hospitals with superior maternal and child facilities in compliance with the original research strategy, as the licensing process takes a long period and research time is limited, so that research is conducted in public hospitals, the excellence of which is not maternal and child services, so that findings for family-centered care programs dependent on the patient setting are collected..

\section{CONCLUSION}

Based on the findings of the study performed in the inpatient room of the TK.II Dustira Hospital and the researcher's conversation, it can be inferred that the characteristics of the parent respondents are deemed to be good for family-centered care facilities based on parental support. Almost all parents were 20-40 years old based on age ( 83,8 percent ). On the basis of the education standard of the respondents mainly highly educated parents are primary school $(37,8 \%)$ and higher education (45.9 percent ). Almost all parents have incomes of more than $\operatorname{Rp} 2$ 
million (81, 1 percent ). Services FamilyCentered Treatment is dependent on support from parents who have demonstrated that virtually all parents (86.5 per cent) provide strong support in a child's inpatient facility. Dustira Cimahi Kindergarten II. Facilities Family-Centered Treatment is dependent on the involvement of nurses almost all nurses (95, 5 per cent) play a well-functioning role in the child's ward. Dustira Cimahi Kindergarten II. Facilities Family-Centered treatment in the healthcare community in the inpatient hospital Tk.II Dustira found that the majority of respondents $(54,1 \%)$ obtained assistance for the hospital environment.

\section{Acknowledgment}

The authors would like to thank their colleague for their contribution and their support to science. They are also grateful to all the reviewers who provided their useful input to the manuscript and helped to complete the document.

\section{Conflict of interest}

The author has no conflict of interest to declare.

\section{REFERENCE}

[1] Apriany, D. (2013). Hubungan Antara Hospitalisasi Anak dengan Tingkat Kecemasan Orang Tua. Jurnal Keperawatan Soedirman, Vol. 8(No. 2), 92-104. http://jks.fikes.unsoed.ac.id/index.php/ $\mathrm{jks} /$ article/view/185/86gmbran

[2] De Fretes, F. (2012). Hubungan Family-Centered Caredengan efek hospitalisasi pada anak di Ruang Dahlian Rumah Sakit Panti Wilasa Citarum Semarang. Artikel Fakultas Kesehatan Universitas Kristen Satya Wacana.

[3] Dunst, C., \& Trivette, C. (2009). Meta-Analytic Structural Equation Modeling of the Influences of FamilyCentered Care on Parent and Child Psychological Health. International Journal of Pediatrics, 2009, 576840. https://doi.org/10.1155/2009/576840

[4] Endah, S.; N.; N. (2018). Hubungan Dukungan Keluarga Dengan Tingkat Kecemasan Anak Usia Sekolah yang Mengalami Tindakan Invasif di Ruang Anak Rsud dr. R. Saedjono Selong Lombok Timur. Prima Jurnal, 4(2), 25-42.

[5] H, Y. (2017). The Relationship between Family Support and the Incidence of Hypertension in the Elderly (Elderly) at the UPT Garuda Health Center.

[6] Jahja, Y. (2011). Psikologi perkembangan. Kencana.

[7] Kusumaningrum. (2010). Application and Strategy of Family-Centered Care Concept in Pre-School Child Hospitalization. Journal of Medicine and Health. https://journal.maranatha.edu/

[8] Sopingi. (2015). PENGANTAR STATISTIK PENDIDIKAN. Mount Samudera Publisher.

[9] Supartini, Y. (2004). Textbook for Basic Concepts of Child Nursing. Jakarta: EGC Publisher.

[10] Utami, Y. (2014). Dampak Hospitalisasi Terhadap Perkembangan Anak. Jurnal Ilmiah WIDYA, 9(2), 920. http://digilib.mercubuana.ac.id/ manager/t\%21@file_artikel_abstrak/Is i_Artikel_891255124583.pdf

[11] Wantiyah, W., A'la, M. Z., Setioputro, B., \& Siswoyo, S. (2018). Validity and Reliability of Critical Care Family Needs Inventory (CCFNI) in Indonesian Version. NurseLine Journal, $\quad 3(2), \quad 115$. https://doi.org/10.19184/nlj.v3i2.9127

[12] Wong, D. L., \& others. (2009). Buku ajar keperawatan pediatrik vol 1 wong.

[13] Yugistyowati, A., \& Wahyuningsih. (2015). Penerapan Family CenteredCare (FCC) Sebagai Program Keberhasilan Perawatan Bayi Prematur. Jurnal Kesehatan Al-Irsyad (JKA), VII(1), 62-74. 